\title{
How do Fab-spaces enable entrepreneurship? Case studies of "Makers" - entrepreneurs
}

\author{
Letizia Mortara ${ }^{1, *}$ and Nicolas Parisot ${ }^{2}$ \\ ${ }^{1}$ Centre for Technology Management, Institute for Manufacturing, University of Cambridge, \\ Department of Engineering, Alan Reece Building, 17 Charles Babbage Road, Cambridge \\ CB3 0FS - UK- Tel: +44 (0) 1223 764831; Fax: +44 (0) 1223 464217, 1m367@cam.ac.uk
}

${ }^{2}$ A.T. Kearney S.A.S., 23 rue de l'Université, 75007 Paris, France. +33 (0)1.56.62.54.90. Nicolas.Parisot@atkearney.com

* Corresponding Author

\begin{abstract}
Fabrication spaces (fab-spaces), such as TechShops or FabLabs, provide access to sophisticated digital manufacturing technologies to individuals. They could be a new institutional context which influences entrepreneurial behaviour. To understand how this might happen, we used a grounded approach to examine the experience of 8 individuals who have benefitted from fab-spaces to push forward their entrepreneurial ventures. This examination led to the development of new hypotheses regarding the potential role of fabspaces in the entrepreneurial journey. In particular, it has emerged that fab-spaces might affect the entry phase of a new venture by lowering the "perception of performance" threshold. Fab-spaces also affect post-entry barriers, as they provide an opportunity to entrepreneurs for fast learning, and consequently, to establish effective routines. However, this paper also shows how these positive effects might be moderated by fab-spaces' institutional setup, chiefly their location and cultural characteristics.
\end{abstract}

\section{KEYWORDS:}

FabLabs, Makespace, Hakerspaces, TechShops, fabrication spaces, Makers, Peer Production, 3D printing, additive manufacturing, barriers to entrepreneurship, crowdfunding, Knowledge Intensive Business Services, Incubators 


\section{Introduction}

In the last few years, the interest in the diffusion and democratization of manufacturing technologies, once mostly only accessible to engineers and designers, has risen significantly (Gershenfeld 2007). An important opportunity to access professional manufacturing technologies is represented by fabrication spaces (fab-spaces), such as Makerspace or FabLabs, where sophisticated manufacturing technologies are available to non-specialists. Fab-spaces provide individuals with access to numerous computer numerical control (CNC) and non-CNC equipment (including additive manufacturing), in order to carry out a variety of projects. Presently, Makerspaces, Hackerspaces, FabLabs and TechShops are amongst the most famous physical fab-spaces, which offer direct use of tools and machines, the chance to meet other like-minded and skilled people, and the opportunity to carry out creative projects. These environments are the cultural hot-bed for the "Maker Movement" (Anderson 2012) which advocates: knowledge sharing, experimentation with new technologies, and the exploration of cross-disciplinary projects motivated by enjoyment and personal achievement. To develop their ideas into products, users could also opt for web-based fab-spaces (Gavetti, Greve et al. 2012). These latter type of fab-spaces, rather than offering the direct use of machines, manufacture goods for the customers on the basis of designs submitted online and mail back the finished products. Their services often include online platforms on which individuals can share, sell and buy object designs (Troxler and Schweikert 2010).

As well as portraying the positive social implications of such creative environments, the media has been reporting numerous examples of products which were developed thanks to fab-spaces, and of new business launched as a result. One example is Oru Kayak (www.orukayak.com), a kayak which can be folded and unfolded in minutes so that it can be stored easily even in small apartments. An even more striking example is that of Makerbot 
Industries, a producer of low-end additive manufacturing equipment for hobbyists and home users that grew out of a fab-space, NYC Resistor ${ }^{1}$.

Whilst not all the users of fab-spaces are necessarily interested in starting an entrepreneurial venture (Moilanen 2012, Dougherty, Thomas et al. 2013), these environments and facilities seem to provide fertile ground for entrepreneurship (Aldrich 2014), and potentially could significantly reduce barriers for the individuals who, under the correct circumstances, might become entrepreneurs (Sarasvathy 2001, Sarasvathy 2004).

This paper is dedicated to analysing the effects fab-spaces may have on the "entrepreneurial journey". As little is yet known about these environments, we took a grounded approach (Glaser and Strauss 1967, Strauss and Corbin 1994) to researching their effects. We interviewed a sample of 8 entrepreneurs (theoretical sampling (Patton 1990)) and examined their accounts of their entrepreneurial venture and its relationships with fab-spaces. A simplified and linear venture creation process was used for analysing the accounts, which was derived merging the venture creation with the new product development processes. During this research we also evaluated how the frequentation and exploitation of the fab-spaces influenced the ventures, in particular in terms of reducing the entrepreneurial entry and postentry barriers (Autio, Kenney et al. 2014).

The paper is structured as follows. In section 2, a literature review is used to derive an appropriate analytical framework for the study, which includes a usable entrepreneurial process (section 2.1), the associated key barriers (section 2.2) and the cultural influence of the context in which the process is immersed (section 2.3). The case study methodology itself is described in section 3. In section 4, results are presented highlighting the particular advantages and the limitations of fab-spaces, identified through the entrepreneurs' accounts.

\footnotetext{
${ }^{1}$ http://makezine.com/2013/05/22/the-difference-between-hackerspaces-makerspaces-TechShops-and-fablabs/ 
Finally, section 5 discusses the most significant practical and theoretical implications of this work.

\section{Literature}

Fab-spaces are a new institutional context (Autio, Kenney et al. 2014, Zahra, Wright et al. 2014) which might influence "entrepreneurial action" (Aldrich 2014).

Several elements concur in supporting this argument. The competencies and resources provided by fab- spaces might increase the chances for individuals to innovate, by improving existing products or by developing totally new ones. This potential for user-driven innovation (Von Hippel 2005) might, in turn, lead to an increase in the number of individuals attempting to establish new ventures and becoming "accidental entrepreneurs" (Shah and Tripsas 2012). Furthermore, fab-spaces are seen as potential providers of manufacturing resources (Birtchnell and Urry 2013, Petrick and Simpson 2013), and hence could support individuals interested in producing, commercialising and propagating their innovation. Also, as the culture and influence of peers is known to affect entrepreneurs' conduct (Nanda and Sorensen 2010), the sharing culture which typifies fab-spaces (Moilanen 2012) might be expected to impact on individuals' entrepreneurial behaviour.

However, not much is yet known about fab-spaces and about how entrepreneurs interact in this type of environment. In response to this gap, this paper takes an exploratory approach, and evaluates the experiences of a group of entrepreneurs in fab-spaces, to understand: How did fab-space influence entrepreneurs? What were the contributions and limitations of these spaces in support to the entrepreneurial action? At what stage of their entrepreneurial process did fab-spaces contribute the most?

As a background to the investigation, we define a generic model and phases of the entrepreneurial venture along which to establish the influence of fab-spaces (session 2.1). 
Further, we draw out the expected barriers along the entrepreneurial process (session 2.2) and the expected cultural influences of fab-spaces (session 2.3).

\subsection{Entrepreneurship, a three-stage process}

A broad template for the entrepreneurial process was initially developed by Bruyat (1993) and later taken up by others (e.g. (Fayolle 2007)). It includes three stages: 1) The initiation of the entrepreneurial process; 2) The commitment to the venture; 3) The completion of the venture. However, there is not yet a clear view of a universal entrepreneurial process and how it deploys (Alvarez, Barney et al. 2013). For instance, scholars take two distinctive views about the starting point of the entrepreneurial activity. Some authors subscribe to the traditional economic view that entrepreneurs "discover" existing opportunities, which are provided by the asymmetries of the environment, by virtue of their own personal circumstances and characteristics. Other authors promote instead the idea that entrepreneurs "create" opportunities through their action (e.g. (Sarasvathy 2001, Alvarez, Barney et al. 2013, Aldrich and Yang 2014)). According to this second school of thought, a particular category of entrepreneurs can be distinguished from the rest, because they become entrepreneurs as a result of their user-innovation activities and their commitment to solving the problems they experience with products. After realising that there is support and demand for their innovations, these individuals might take the decision to start a new venture. This category is referred to as "user-" or "accidental" entrepreneurs, and their process has been highlighted by recent works (Shah and Tripsas 2007).

However, Shane and Venkataraman's definition of entrepreneurship is the "scholarly examination of how, by whom, and with what effects, opportunities to create future goods and services are discovered, evaluated, and exploited" (Shane 2000)(p. 219). This shows that the entrepreneurship concept is broad, and that different types of entrepreneurial operations such as production, innovation, start-ups, new ventures, corporate venture spin-outs and spin- 
ins are included under the umbrella of this discipline (Woo, Cooper et al. 1991, Jennings, Greenwood et al. 2013).

Despite the various views about entrepreneurial typologies and processes, it is generally acknowledged that, as part of the process of venture creation, entrepreneurs need to look after the development (from ideation to production) of new product/service concepts. This phase of the venture creation process is differently interpreted, and made explicit, by entrepreneurship scholars. It is often not described, but only signposted as a necessary part of the venture creation process, for example in the work of scholars such as Bhave (1994), who refers to it as the "product and product development" phase, at the boundary between the "technology setup and organisation creation" and the "exchange" stages of venture creation. Others identify that, rather than being chronologically bound to a specific stage of venture creation, technology (products) and organizations often coevolve (Shah and Tripsas 2007, Brem 2011, Shah and Mody 2014).

In agreement with Brem (2011), we think that in the entrepreneurial path, often several processes overlap. One relates to innovation-new product development, to which a good amount of effort is devoted. The "Ideation, Conversion, Diffusion" process (Hansen and Birkinshaw 2007) is a classic template to describe this innovation activity within any firm (Brem 2011).

As fab-spaces are frequented by "Makers" (Anderson 2012), who are characterised by the desire to tinker and develop interesting projects, it is reasonable to assume that the entrepreneurs frequenting these spaces would be engaging in some form of innovation or product development activity. Following this logic, and given that we do not know in advance what particular type of entrepreneurial individuals we would meet, a simple three- 
stage model is derived which attempts to coarsely describe the entrepreneurial process, merging the venture development with the new product development phases.

\section{Stage 1: IDEATION and opportunity recognition. The individual finds an idea and} understands its potential embedded commercial value. This stage includes the opportunity recognition (Shane and Venkataraman 2000, Ardichvili, Cardozo et al. 2003), and the problem solving phase of new product concept ideas (Shah and Tripsas 2007), which could be assimilated with new inventions (Utterback 1971) whose value is assessed (Brem 2007).

\section{Stage 2: DEVELOPMENT and conversion. The individual develops his idea towards a} product concept and tests its manufacturability and feasibility. The initial concepts or ideas need to be improved, developed and refined in order to achieve technically robust and manufacturable designs (Ries 2011). In this development process, several variations of the original ideas might be conceptualised and assessed, leading to the selection of a product design and a manufacturing process (Roper, Du et al. 2008). To this end, prototyping has been demonstrated to be particularly helpful (Mascitelli 2000) for the generation of variants of the original concept (Bogers and Horst 2014), the selection of the best ones (Hansen and Birkinshaw 2007), and of the best production technology (Bhave 1994).

Stage 3: PRODUCTION, DIFFUSION and commercialisation. Here, individuals work towards scale up to launch the production, and try to reach a market. To reach a market, entrepreneurs need to establish production capabilities, including a production supply chain (Bhave 1994; Hitt, Ireland et al. 2001), to "spread the new products, businesses, and practices across desirable geographic locations, channels, and customer groups" (Hansen and Birkinshaw 2007). 


\subsection{Barriers along the entrepreneurial process}

Autio et al. (2014) propose to concentrate on two key levels when studying the effect of the context on the entrepreneurial-innovation ventures: entry and post-entry effects. Entry effects impact on the decisions to engage in entrepreneurial behaviour and continue to influence the strategic decisions of the entrepreneurs throughout their ventures. The factors deriving from the characteristics of the individual that self-selects to become an entrepreneur could be encompassed under this umbrella (e.g. their personal background and motivations). In this respect, Degeorge and Foylle argue that at this level both 'intention' and 'displacement' affect the start of the entrepreneurial process (2011).

Post-entry effects refer to the influencers which kick-in once the venture has started and will concern "the perceived desirability or feasibility associated with alternative entrepreneurial actions" (Autio, Kenney et al. 2014). When at the center of the new venture there is a new product to be developed, as expected in the case of entrepreneurs who interact with fabspaces, these two types of barriers overlap with the obstacles to new product development or innovation. Hence, entrepreneurs will face "deterring" barriers which prevent the subjects from committing to innovation, and "revealed barriers", which concern the challenges met within the innovation process and can be overcome through learning, through direct and indirect experience (D'Este, Iammarino et al. 2012). For young and unestablished firms, amongst the deterring barriers, D'Este et al. (2012) recognize the lack of resources and capabilities, in both organizational and technological aspects (Katila and Shane 2005) as well as the unfavorable market structures (D'Este, Iammarino et al. 2012). Taking a ResourceBased View (Barney 2001), and its extension in the Knowledge- Based View, fab-spaces could be seen as providers of resources and competences. As for larger firms, a venture could be progressed via accessing different types of complementary resources through the relationship with other providers (Miotti and Sachwald 2003). 
Fab-spaces could be an opportunity to access a number of professional-grade machineries to otherwise resource-constrained entrepreneurs and hence contribute to lower the deterring barriers. Further, as fab-spaces are attended by individuals with wide ranging backgrounds, they could hence also be providers of expertise (know-how and know-what) and might be useful in the identification of networks of other competence providers (know-who) which are known to aid the entrepreneurs at different stages along the venture path (Martinez and Aldrich 2011, Tidd 2014).

Further, entrepreneurs need to learn by going through a path of establishing, adapting and abandoning routines (Aldrich and Yang 2014). Hence, if fab-spaces will be demonstrated to be conducive to learning and developing appropriate routines, they could be seen as environments which lower the revealed barriers.

\subsection{Interactions of entrepreneurs at fab-spaces}

The cultural characteristics of the environment around entrepreneurs have been shown to influence the entrepreneurial journey, in that they provide the "[...] norms, values, legitimacy and justifications of worth that have consequences for supporting or discouraging entrepreneurial behaviour" (Thornton, D. et al. 2011). Fab-spaces are new environments and can be characterised by varying cultural norms (Moilanen 2012, Moilanen and Vadén 2013). Some fab-spaces originate from a particular socio-cultural context - rooted in the software "hacker" and "Open source" movements - which in some instances advocates for particular forms of economic and social transformations (Rigi 2013). How are these aspects of the context influencing the entrepreneurial behaviour/journey?

As a result of this literature analysis, the research framework in Fig. 1 could be derived and used as an exploratory lens. 


\section{Methodology}

This research was conducted in 2013 (May - August), during a period when fab-spaces started to become more widespread. The work aimed to provide an initial view of how entrepreneurs interact with fab-spaces, and how in turn these support entrepreneurs in their process of developing and launching their products and ventures.

The aim was pursued via a holistic multiple-case design methodology (Yin 2009), based on grounded theory (Glaser and Strauss 1967, Strauss and Corbin 1994). This research design was deemed suitable because of the relatively little prior work available on this emerging phenomenon, and because it is particularly useful to link the significance of events in people's minds with the symbols they adopt to express those meanings (Glaser and Strauss 1967).

Data were captured through semi-structured interviews (see sample selection and data gathering in section 3.1). The literature review was performed to identify the area of investigation and a direction for the analysis of the data (see section 3.2 for the description of the data analysis approach).

\subsection{The sample}

Our sampling should be considered theoretical (Patton 1990), looking for pertinent and datarich cases. Interviewees were sought in various locations (in the USA and Europe), amongst the people who used fab-spaces. We prioritized those who were using such spaces with the idea of pursuing new ventures and who were in advanced development or commercialization stages of their products. This focus enabled a more reliable account of the realised benefits of fab-spaces, rather than of projected benefits. Within these constraints, we attempted to gather a broad overview of perspectives, endeavouring to include a spectrum of entrepreneurial venture types. We included experiences from people whose business venture process seemed consistent with user-entrepreneurship processes, serial entrepreneurs and nascent 
entrepreneurs, individuals who pursued a manufacturing venture, and those who attempted to establish themselves as artists and designers.

At the time of this research, we were aware that several models of fab-spaces had started to emerge. As there is still a limited knowledge about these organisations, and a definitive typology is still unavailable, we included interviews with individuals who had experience of different fab-spaces, in various locations, to attempt to encompass more variety.

To identify the case studies, an e-mail was sent to 20 fab-space managers in USA and Europe, asking them for the contact details of individuals who used, or were using, their fabspace to develop products for commercial purposes. A request for involvement was also posted directly in fab-spaces' mailing lists or discussion groups such as http://hackerspaces.org/wiki/ and http://wiki.fablab.is. Through this method, we identified 8 individuals who were available to discuss their experience of developing their venture, and their views of how fab-spaces supported them (see table 1).

A free-form interview protocol was used. However, to remind the interviewer of the breadth of information sought, a questionnaire was compiled (see the outline of questions in appendix 1), but not strictly enforced, to allow entrepreneurs as much freedom of expression as possible. The interviews lasted approximately 1 hour and were conducted telephonically. All interviews were tape-recorded and later transcribed verbatim ${ }^{2}$. The interviewee was firstly given a quick account of the research topic, and then was asked to talk freely about his/her experience and the role that the fab-space(s) played in their entrepreneurial process. When the interviewees naturally exhausted their flow, the interviewer asked further questions with the intention of teasing further the entrepreneurs' narratives. For instance, the interviewer asked

\footnotetext{
2 The interviews in French were transcribed by a French-born researcher in English. The interviewees' comments in quotations are translations that attempt to capture the true nature and intonation of what was said in French

Version 3 - FINAL - Accepted in the Special Issue "3D Printing: the Next Industrial Revolution” Int. J. of Manufacturing Technology and Management

Prof. Irene Petrick, Prof. Thierry Rayna, Dr. Ludmila Striukova, Eds
} 
for clarification and for more details, attempting to cover the interaction with fab-spaces along the 3 stages defined in section 2.1 above (ideation, development and commercialization). This "life stories" or "narrative" method poses an emphasis on how interviewees express themselves and their identity by the references they make to past, present, and future actions and by the expressions they choose (Lieblich, Tuval-Mashiach et al. 1998).

We focused on specific part of interviewees' lives rather than documenting whole life stories (Elliot 2005). Table 2, reports a brief account of each individual's entrepreneurial journey, pertinent to their use of fab-spaces. 


\begin{tabular}{|c|c|c|c|}
\hline & & Entrepreneur's Background & Fab-spaces used \\
\hline $\begin{array}{l}\text { A } \\
\text { Serial } \\
\text { entrep. } \\
\text { Social } \\
\text { entrep. }\end{array}$ & USA & $\begin{array}{l}\text { After obtaining a business degree, A worked for few firms in Texas and then developed his own software business for a } \\
\text { couple of years. Then "just got very tired of sitting in a cubicle and looking at a screen and decided [he] wanted to make } \\
\text { things in the real world". He quitted his office job and developed his first venture. He then moved to California where } \\
\text { "[he] now make[s] things as [his] primary job". He is developing a number of ventures, some with the intention to } \\
\text { support farmers and local communities in Africa. His current idea - a social gardening assistant is a box which } \\
\text { automatically regulates the soil moisture, the light and the temperature to keep food growing optimally. Moreover, it } \\
\text { shares updates with the owners' virtual friends, letting them gain experience about how to best grow different plants. }\end{array}$ & $\begin{array}{l}\text { Instructables } \\
\text { TechShop }\end{array}$ \\
\hline $\begin{array}{l}\text { B } \\
\text { Designer } \\
\text { entrep. }\end{array}$ & USA & $\begin{array}{l}\text { After a degree in art, B worked as a teacher for several years. He soon got tired of the job as he felt it did not provide } \\
\text { enough time to pursue his own artistic projects. He wants to pursue a self-employed career developing artistic artefacts. } \\
\text { He is currently working at a table lamp, with an oak, digitally cut, paper top. }\end{array}$ & Hackerspace \\
\hline $\begin{array}{l}\text { Nascent } \\
\text { entrep. }\end{array}$ & & & \\
\hline $\begin{array}{l}\text { C } \\
\text { User } \\
\text { entrep. }\end{array}$ & USA & $\begin{array}{l}\text { With a degree in computer engineering, C works for a software company but has developed a personal interest for } \\
\text { hardware and has the ambition to develop a small Wi-Fi-controlled flying gadget. He has not yet made plans for a fully- } \\
\text { fledged business, but, having been successfully backed by crowdfunding, he wants to deliver on his pledge and consider } \\
\text { how to scale up his business through further crowdfunding campaigns. }\end{array}$ & $\begin{array}{l}\text { Hackerspace } \\
\text { Shapeways } \\
\text { TechShop }\end{array}$ \\
\hline $\begin{array}{l}\text { Nascent } \\
\text { entrep }\end{array}$ & & & \\
\hline $\mathbf{D}$ & FRA & $\begin{array}{l}\text { With a degree in political science, } \mathrm{D} \text { has been bought out of his share in his previous successful business by one of his } \\
\text { partners. With the amount received he is pursuing the development of a new business, based on a market need identified }\end{array}$ & Hackerspace \\
\hline
\end{tabular}

Version 3 - FINAL - Accepted in the Special Issue "3D Printing: the Next Industrial Revolution"

Int. J. of Manufacturing Technology and Management

Prof. Irene Petrick, Prof. Thierry Rayna, Dr. Ludmila Striukova, Eds 


\begin{tabular}{|c|c|c|c|}
\hline $\begin{array}{l}\text { Serial } \\
\text { entrep. }\end{array}$ & & $\begin{array}{l}\text { in his previous company: a prevention system for deterring merchandise theft. To do so he is upgrading the technology } \\
\text { and product system and he is acquiring customers. }\end{array}$ & $\begin{array}{l}\text { University-organised } \\
\text { fab-space }\end{array}$ \\
\hline $\begin{array}{l}\text { E } \\
\text { Designer } \\
\text { entrep. }\end{array}$ & USA & $\begin{array}{l}\text { With a design degree, E has the ambition of becoming recognized as a designer and of developing innovative products } \\
\text { for the fashion industry. Her current idea concerns the sale of her jewelry range. She has been backed on by a } \\
\text { crowdfunding community for this purpose. }\end{array}$ & TechShop \\
\hline \multicolumn{4}{|l|}{$\begin{array}{l}\text { Nascent } \\
\text { entrep. }\end{array}$} \\
\hline $\begin{array}{l}\text { F } \\
\text { User } \\
\text { entrep. }\end{array}$ & USA & $\begin{array}{l}\text { With a degree in botany, F attempted a number of businesses, some of which more successful ("successfully sold") than } \\
\text { others. This is a deliberate lifestyle choice: "I have been an entrepreneur for quite a long time, I do not think I ever- I } \\
\text { rarely worked for someone else". He founded a supportive group of entrepreneurs who meet regularly. Identifying the } \\
\text { benefits of working at a computer from a standing position, he decided to develop a special desk and to build a business } \\
\text { around it. }\end{array}$ & TechShop \\
\hline $\begin{array}{l}\text { Serial } \\
\text { entrep. }\end{array}$ & & & \\
\hline $\begin{array}{l}\text { G } \\
\text { Nascent } \\
\text { Entrep. }\end{array}$ & FRA & $\begin{array}{l}\text { G studied engineering. With a group of friends had the intention of starting an engineering business to develop } \\
\text { agricultural robots after finishing the studies. An automatic agricultural robot is their business idea, defined after a } \\
\text { market research with the local farmers. After initially being rejected by the local business incubator as their idea was } \\
\text { still too weakly developed, they were eventually accepted after having developed the first working prototype with the } \\
\text { support of the local FabLab community and having obtained funds through crowdfunding. }\end{array}$ & Fab Lab \\
\hline $\begin{array}{l}\text { H } \\
\text { User } \\
\text { entrep. }\end{array}$ & USA & $\begin{array}{l}\text { With an engineering degree, working knowledge of batteries and a passion for outdoor sports, } \mathrm{H} \text { decided that he wanted } \\
\text { to develop a lightweight and compact lamp. After starting developing this idea in his spare time, the project took on and } \\
\text { he pursued the scale-up of a fully-fledged new venture. }\end{array}$ & $\begin{array}{l}\text { TechShop } \\
\text { Shapeways }\end{array}$ \\
\hline
\end{tabular}

Version 3 - FINAL - Accepted in the Special Issue "3D Printing: the Next Industrial Revolution"

Int. J. of Manufacturing Technology and Management

Prof. Irene Petrick, Prof. Thierry Rayna, Dr. Ludmila Striukova, Eds 


\begin{tabular}{|l|l|l|l|}
\hline $\begin{array}{l}\text { Nascent } \\
\text { entrep. }\end{array}$ & & & Own community of \\
tinkerers & \\
\hline
\end{tabular}

Table 1 Entrepreneurs interviewed

Version 3 - FINAL - Accepted in the Special Issue "3D Printing: the Next Industrial Revolution" Int. J. of Manufacturing Technology and Management

Prof. Irene Petrick, Prof. Thierry Rayna, Dr. Ludmila Striukova, Eds 


\begin{tabular}{|c|c|}
\hline Case & Chronology \\
\hline $\mathbf{A}$ & $\begin{array}{l}\text { A came up with his idea at home. He developed a first CAD model and prototype at home which was functional but far from the finished version. He posted his } \\
\text { designs on "The Instructables" online platform and got feedback from this community to improve the prototype. He then ordered } 100 \text { PCBs from an external } \\
\text { supplier, manufactured } 100 \text { products at home and sold these as DIY kits on the Internet to get early feedback from buyers. Despite receiving useful feedback from } \\
\text { the first users he did not develop another product version for } 3 \text { years because he lacked tools and time. In } 2012 \text { he moved to California where he subscribed to the } \\
\text { local TechShop. He became an instructor and took many advanced classes to get qualified on almost every machine. Moreover, he learnt to solder components on } \\
\text { circuit boards thanks to the help of other members. He developed twenty prototypes within three months while at TechShop, where the staff and the other } \\
\text { members provided him with advice in design and engineering, to finally get a pre-production prototype ready. He received advice from other TechShop members } \\
\text { who knew local PCB suppliers and helped him to select one. Meanwhile, he developed a production process, thanks to the help of other members and launched a } \\
\text { crowdfunding campaign. By the time he had finished to develop his production process, he had raised funding. He ordered } 100 \text { PCBs and manufactured } 100 \\
\text { products with the TechShop capabilities, which he shipped to his crowdfunding supporters and other customers. He is now developing a third version of his } \\
\text { product with new features at TechShop. However, his next production will be outsourced as the tools provided by the TechShop are inadequate to manufacture } \\
\text { this new product. }\end{array}$ \\
\hline B & $\begin{array}{l}\text { B has been a member of a local hackerspace since } 2008 \text { where he learned about Arduino and the potential of this technology. His ambition is to produce artistic } \\
\text { artefacts. He had this passion since his studies at college. After leaving a teaching job, he developed one idea for an interactive lamp while watching other } \\
\text { hackerspace members using tools and by looking at products on "The Instructables" online platform. He started to show drawings of the product to other members } \\
\text { and through their feedback selected the design to prototype. Then he developed a first CAD design thanks to low-end design software provided by the fab-space } \\
\text { and, using the mill and the laser cutter, developed the first prototype. He benefitted greatly from the help of other fab-space members also in the product } \\
\text { development process. He specifically remembers two participants who were really helpful: a retired scientist who had worked for an OEM and another very } \\
\text { knowledgeable member who frequented the fab-space almost daily and offered consistently to help others. Once his prototype was ready for production, B posted } \\
\text { a message on the fab-space discussion group to ask whether other members would be interested in buying parts in bulk from China to reduce the shipping cost and } \\
\text { made a common order. Once he received his parts, he manufactured few lamps at hackerspace and sold them via an art gallery. At the time of the interview, B was } \\
\text { planning a crowdfunding campaign and the development of a website on which he could sell his products. For this also, he was counting on the support of the fab- } \\
\text { space members many of whom had web design skills. }\end{array}$ \\
\hline $\mathbf{C}$ & $\begin{array}{l}\text { C came up with his idea of developing a new flying gadget discovering an increasing interest on hardware. The idea came whilst watching videos on YouTube } \\
\text { and thought of how to improve the existing products' features. C first developed a CAD design with low-end CAD freeware and tutorials available on the Internet. } \\
\text { He then subscribed to a local Hackerspace. As he could not access the laser cutter and the 3D printer as often as he needed as they were respectively always } \\
\text { booked or broken, he turned to Shapeways to get his parts. The parts were returned in three weeks but were not yet right. Concerned about further costs and } \\
\text { waiting time decided not to continue using web-based fab-spaces. Instead, he used the tools available at the Hackerspace to modify the parts he had received via } \\
\text { Shapeways and developed a new prototype, which unfortunately did not function. The Hackerspace was not equipped with tools to measure electronic signals and } \\
\text { figure out the problem. When a TechShop opened in the area, he subscribed to it and took classes to use the 3D Printer and laser cutter. Within a day, he managed }\end{array}$ \\
\hline
\end{tabular}

Version 3 - FINAL - Accepted in the Special Issue "3D Printing: the Next Industrial Revolution"

Int. J. of Manufacturing Technology and Management

Prof. Irene Petrick, Prof. Thierry Rayna, Dr. Ludmila Striukova, Eds 


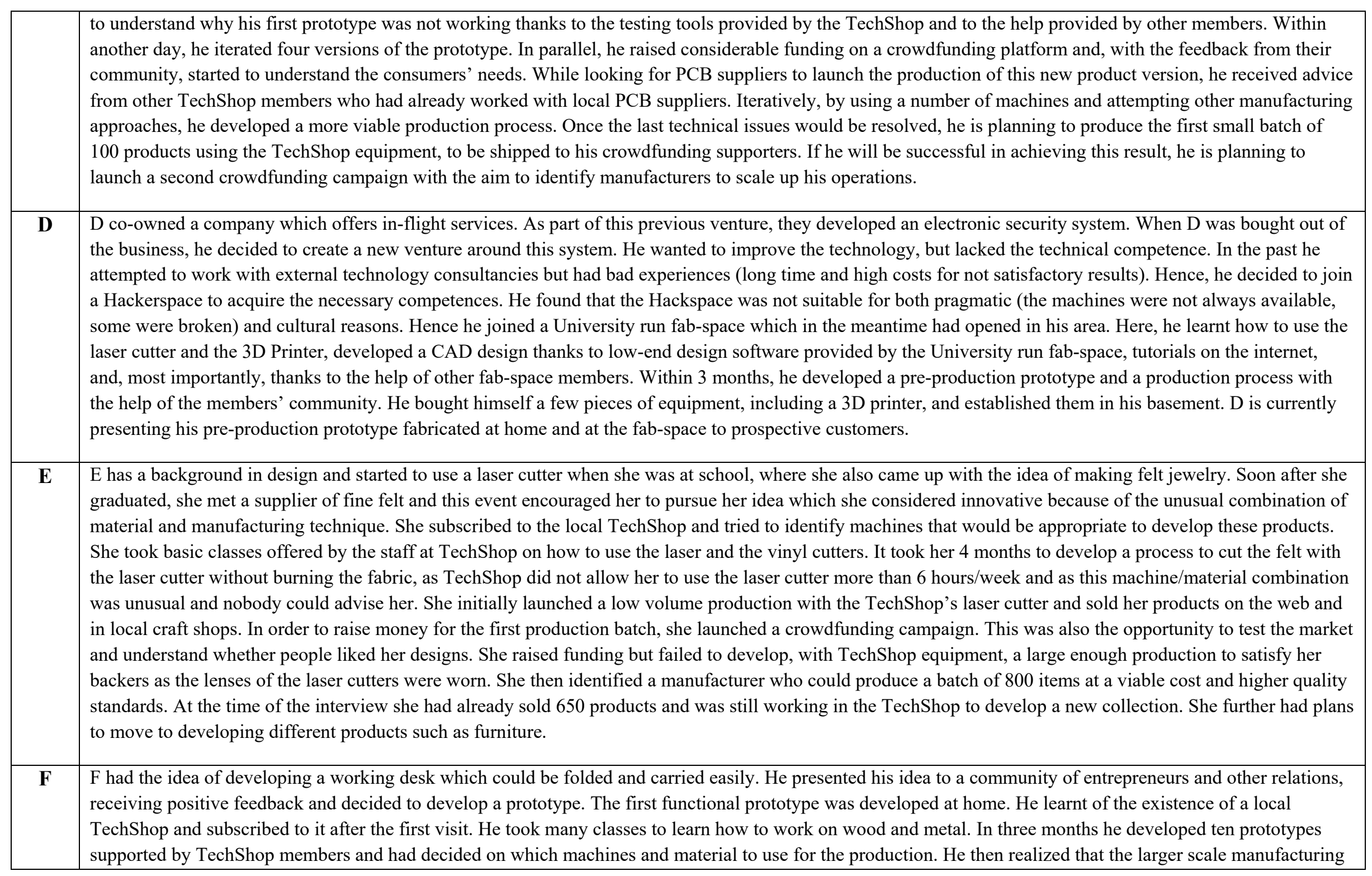

Version 3 - FINAL - Accepted in the Special Issue "3D Printing: the Next Industrial Revolution"

Int. J. of Manufacturing Technology and Management

Prof. Irene Petrick, Prof. Thierry Rayna, Dr. Ludmila Striukova, Eds 


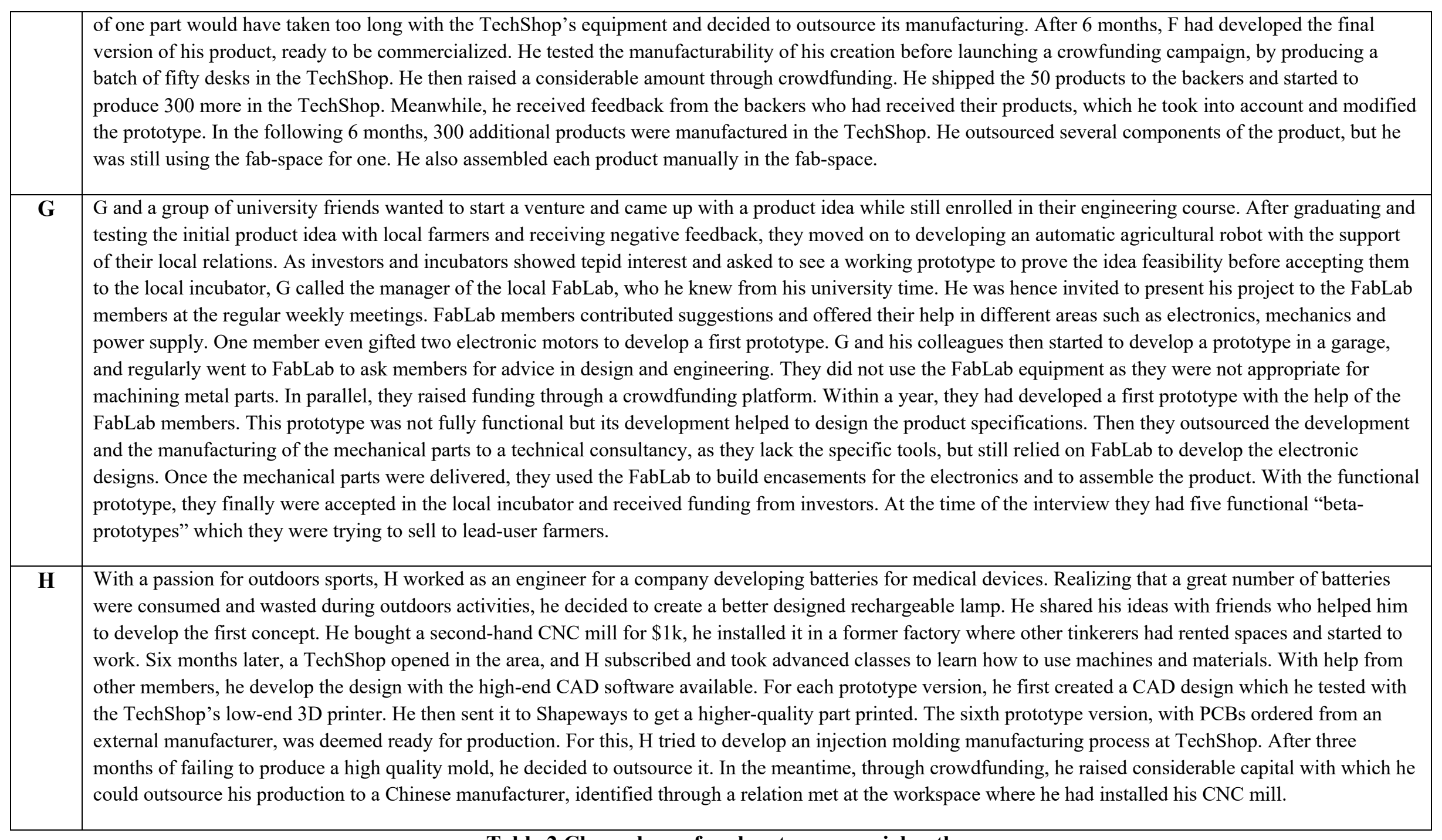

Table 2 Chronology of each entrepreneurial path 


\subsection{Data Analysis}

For the analysis, we started by constructing chronologies for each entrepreneur's story (see table 2), looking for common elements (Elliot 2005). In the meantime, we proceeded to analysing content - through iterative stages, starting with open coding (Creswell 2003) - whereby each story was read multiple times to identify significant elements of interaction between the entrepreneur and the fab-spaces, along the 3 steps process developed in section 2.1. These elements included for example, reasons and timing to approach the fabspace, competences and resources available, opinions regarding their usefulness or limitations, experiences with the staff (or about other people at the fab-space), significant events, chronology, and other resources that concurred to help them move forward and their link with the fab-spaces (if any). Progressed codes (and process phases) were obtained by reviewing and re-reviewing the data to expand open codes (Creswell 2003), systematically tabulating the quotes on a template, which captured the product development/venture process on one axis and, on the other, a time line (consisting of before the interaction with fab-space, at fabspace, after/other actions outside the fab-space). By doing so, second order themes emerged from each case. These were carried over to the next case and complemented with new emerging codes. As a result, data were mapped (a portion is portrayed in Fig. 2 as an example). After this within-case analyses, a cross-case analysis was performed, looking for similarities and differences across the interviewees' stories (Yin 2003). At this point, we started reflecting the observations against theory (Creswell 2003).

\section{Results}

Starting with the identification of which stages in the interviewees' entrepreneurial process were supported by fab-spaces, this section reports also their views about the advantages and limitations of these organisations.

\subsection{At what stage of their venture/product development process did the entrepreneurs use fab-spaces?} As a result of the analysis, the entrepreneurial process, developed through literature review (section 2.1), was refined. As part of the "development" stage, product and process (manufacturability) designs were made explicit. The Production/Commercialisation phase was split into 1) Small batch production; 2) Scale-up production; 3) Marketing, as these were mentioned by the interviews as separate phases/tasks to which they were giving attention. Table 3 reports an example of these steps taken from the narrative of case F. 


\begin{tabular}{|c|c|c|c|c|c|c|}
\hline & IDEATION & \multicolumn{2}{|c|}{ DEVELOPMENT } & \multicolumn{3}{|c|}{ PRODUCTION } \\
\hline & Ideation & Product design & Manufacturability & $\begin{array}{l}\text { Small Batch } \\
\text { production }\end{array}$ & Scale Up & Marketing \\
\hline $\mathbf{F}$ & $\begin{array}{l}\text { I've been an } \\
\text { entrepreneur for } \\
\text { quite a long time, } \\
\text { [..]I've been using a } \\
\text { standing desk for a } \\
\text { little while, just } \\
\text { something kind of } \\
\text { mishmash made } \\
\text { from a kitchen } \\
\text { rack, and it was } \\
\text { such a crucial thing } \\
\text { for me [..]. This } \\
\text { type of desks are } \\
\text { really expensive } \\
\text { out on the market } \\
\text { [..]. }\end{array}$ & $\begin{array}{l}\text { I discovered } \\
\text { TechShop, and that } \\
\text { was when I decided } \\
\text { to go in, check it } \\
\text { out, and take a } \\
\text { tour, and realised } \\
\text { there that they had } \\
\text { so many more } \\
\text { tools, and so many } \\
\text { more abilities, } \\
\text { things for me to be } \\
\text { able to solve the } \\
\text { prototype. }\end{array}$ & $\begin{array}{l}\text { I took an injection } \\
\text { molding class. I have } \\
\text { never made a mold, } \\
\text { and I have never } \\
\text { injection molded on } \\
\text { that machine as of } \\
\text { yet; but I still found it } \\
\text { to be one of the more } \\
\text { valuable classes, } \\
\text { because [... it taught } \\
\text { me some of the } \\
\text { theory behind what to } \\
\text { do, and then that } \\
\text { helped me to do } \\
\text { something that was } \\
\text { very important, } \\
\text { called design for } \\
\text { manufacture. Those } \\
\text { classes helped me } \\
\text { understand the } \\
\text { process that might be } \\
\text { used to manufacture, } \\
\text { so that I could alter } \\
\text { my designs to make } \\
\text { sure that I actually } \\
\text { could get it } \\
\text { manufactured. }\end{array}$ & $\begin{array}{l}\text { A couple of weeks } \\
\text { before I even } \\
\text { launched the } \\
\text { [crowdfunding], I } \\
\text { was beginning to } \\
\text { do the first run. I } \\
\text { was going to do a } \\
\text { run of about } 50 \\
\text { desks. That was } \\
\text { kind of a test run of } \\
\text { manufacturing at } \\
\text { lower level [... }\end{array}$ & $\begin{array}{l}\text { I have a sewing } \\
\text { house in the East } \\
\text { Bay that I use, and } \\
\text { the poles come } \\
\text { from, of course, a } \\
\text { manufacturing } \\
\text { company over, I } \\
\text { believe, in Utah or } \\
\text { Pennsylvania. And } \\
\text { then the straps } \\
\text { came from a place } \\
\text { in Georgia, and I } \\
\text { did all the assembly } \\
\text { myself. I cut the } \\
\text { inserts at the } \\
\text { TechShop, the } \\
\text { wood inserts that } \\
\text { go into the desk, } \\
\text { and I also } \\
\text { fabricated the metal } \\
\text { brackets at the } \\
\text { TechShop. }\end{array}$ & $\begin{array}{l}\text { I started doing } \\
\text { some marketing for } \\
\text { that very early, and } \\
\text { getting people on } \\
\text { mailing lists. }\end{array}$ \\
\hline
\end{tabular}

Table 3 - Example from case $F$ along the emerging venture creation/new product development process

Table 4 reports where interviewees indicated that fab-spaces had the strongest contribution within the refined venture creation/product development process (see Table 3). The recognition of the entrepreneurial opportunity (Shane 2000) always happened outside fab-spaces, as each interviewee detailed how his/her prior knowledge about a problem (Shane 2000), or their personal motivation to start a self-employed career, were at the basis of their entrepreneurial venture. Only B described the frequentation of fab-spaces as an inspiration for his products. However, even in this case, the inspiration from the fab-space was related to the ideation of a new product and its features rather than about the idea of starting a business.

The cases analysed showed instead a marked impact of fab-spaces on the development of prototypes

(product design), and most interviewees (A, B, C, E, F, H) commented how the direct experience with the manufacturing of their prototypes at fab-spaces made them realise the importance of identifying the most viable production route. Further, A, B and F developed their small-scale production using fab-space tools 
and facilities, whilst $\mathrm{E}$ attempted this route but had to abandon it. Still working with batch production, $\mathrm{F}$ started scaling up the manufacturing of his products, still using the fab-space facilities to produce some parts.

\begin{tabular}{|c|c|c|c|c|c|c|}
\hline & IDEATION & \multicolumn{2}{|c|}{$\begin{array}{c}\text { DEVELOPMENT } \\
\text { PRODUCTION }\end{array}$} & \multicolumn{3}{|c|}{ COMMERCIALISATION } \\
\hline & Ideation & $\begin{array}{c}\text { Product design } \\
\text { (prototype) }\end{array}$ & $\begin{array}{c}\text { Manufacturability } \\
\text { (prototype) }\end{array}$ & $\begin{array}{c}\text { Small } \\
\text { Batch } \\
\text { Production }\end{array}$ & $\begin{array}{c}\text { Production } \\
\text { Scale-up }\end{array}$ & Marketing \\
\hline $\bar{A}$ & & & TechShop & & & \\
\hline $\mathbf{B}$ & & & rerspace & & & \\
\hline $\mathbf{C}$ & & $\begin{array}{r}\text { Hackerspace/ } \\
\text { TechS }\end{array}$ & eways & & & \\
\hline $\mathbf{D}$ & & $\begin{array}{c}\text { Hackerspace } \\
\text { University fab- } \\
\text { space }\end{array}$ & & & & \\
\hline $\mathbf{E}$ & & & Shop & & & \\
\hline $\mathbf{F}$ & & & TechSh & & & \\
\hline G & & FabLab & & & & \\
\hline $\mathbf{H}$ & & $\begin{array}{c}\text { Own Community } \\
\text { TechShop } \\
\text { Shapeways }\end{array}$ & & & & \\
\hline
\end{tabular}

Table 4 - Summary of the stages in the New Venture/New Product Development process where interviewees associated the highest impact/interaction with fab-spaces 
4.2 What were the advantages of fab-spaces in the eyes of entrepreneurs?

\subsubsection{Acquiring resources and competences}

A) Knowledge: All entrepreneurs mentioned accessing knowledge directly or indirectly as one of the key benefits received at fab-spaces. Know-how (e.g. technical skills), know-what (e.g. understanding what skills were needed) and know-who (e.g. accessing other's network via the frequentation of fab-spaces), were all mentioned as important advantages. For the acquisition of the know-how, teaching classes were mentioned by several interviewees as an initiation in the use of machines, whilst the expertise of the community of other members and staff was emphasized more strongly as pivotal for the success of ventures. In particular, because this was highly qualified expertise, "There is a retired rocket scientist at [hackerspace]. I am not joking! [..]” (B) "You have pensioners, who are wonderful. In the [university fabspace], [..] there are a few guys ranging from 65 to 80 years old. They're engineers with 30 to 35 years of experience in industry. They know their stuff.” (D). Although those who frequented different fab-spaces seemed to indicate that the level of expertise was variable: "At hackerspaces, the community there, it is a little more interesting [..] Hackerspace, kind of, attracts a lot more experts. I think TechShop attracts a lot more hobbyists" (C).

The value of this expertise was often mentioned in comparison with that obtained from external consultancies in terms of money and time. To start with, the fact that knowledge is available at short notice, ready to be tapped ad hoc for specific needs was considered important: “[..] working at TechShop I was able to just run into someone there who was an expert on it [..], he walked me through it. It took him 10 minutes, but it saved me huge amounts of money and headache." (A). "Finding a good consultant is a job on its own, you know? [..] You get to focus group ready for you all the time if you want [..] Yes, you've got key people that act like, I don't know, private consultants that you would pay tonnes.” (B).

However, also the long term benefits of acquiring these skills were emphasized: for instance, entrepreneur D felt that technical knowledge was a key missing skill in his small venture, and attributed to this ignorance the previous failures with external design consultancies. "I wanted to understand how it was possible to make things, to be in a position to have an informed discussion about prototyping. (D)", and “They

[members at fab-space] made me discover some technological applications that I find inspiring and helpful Version 3 - FINAL - Accepted in the Special Issue "3D Printing: the Next Industrial Revolution" Int. J. of Manufacturing Technology and Management

Prof. Irene Petrick, Prof. Thierry Rayna, Dr. Ludmila Striukova, Eds 
for a number of future projects. They have stimulated my creativity.” (D). As a result, several entrepreneurs saw fab-spaces as opportunities to stock up on technical competences: "I was able to take all the classes for free. [..] I just started learning as much as I could and ask people as many questions as possible [..].”(H). The know-who was particularly mentioned in the context of identifying people whose competences would be helpful for the latter stages of the process (e.g. manufacturing supply chain, marketing, IP protection (B, $\mathrm{F}, \mathrm{H})$ ).

B) Resources: The quality and availability of tools were highlighted as fundamental (e.g. "They had all this equipment that is just absolutely phenomenal and something I could never even consider affording: $\$ 100,000$ machines, million of dollars of equipment that I could justify with $\$ 130$ a month just to use it. It's basically a gym membership.” (C)). Testing equipment to appreciate why products did not operate (e.g. electronic), were repeatedly mentioned. However, some (e.g. B, F, G) also emphasized that, through fabspaces, materials were more easily accessible than elsewhere, both directly via the fab-space (e.g. "Usually the things that TechShop has, the materials, they tend to be better- they tend to be cheaper through the TechShop than they are actually in other places." (F)) or because the community self-organises to order in bulk (e.g. “Other people when they're ordering stuff, usually post [on the internal mailing list] and if you order more than $\$ 1 \mathrm{k}$ worth of stuff, everybody gets this $20 \%$ discount.” (B)).

The availability of knowledge and resources at an accessible cost implies a higher freedom to experiment with daring projects (e.g. "[having all these equipment available] makes you more willing to try a crazy idea, because the price of failure is also consequently way lower.” (B); "It opens up possibilities of what someone can do by themselves or with a small group of people” (C)) or to overcome personal limitations (e.g. "I was able to learn things that I didn't know before at all like surface mount sawing, I was very intimidated by it." (A)). On top of this, it helps the firm to achieve more professional results with reduced resources, with the consequence that it rises the perception of the value of the venture in the eyes of important stakeholders. For instance, D managed to present a convincing prototype to the prospective clients ("I was [..] in competition against a company with several thousands [of] engineers working for them, and our project was credible.", whilst G managed to obtain funding from investors and be accepted by a local 
incubator, who previously denied their support, because they had developed a working prototype with the help of a fab-space.

\subsubsection{Learning opportunity}

Besides the advantages above, most interviewees mentioned the opportunity to shortcut their learning curve. At the top was the opportunity to iterate designs quickly and to learn what works and what does not in their prototypes. This advantage was again mentioned in comparison to what happens when relying on other types of external services (e.g. So [..] I have been able to come up with this idea and to rapidly experiment with new concepts [..] on the same day that I had the idea. [Whilst] Even if you have these 3D models ordered online, it still takes a month [..]. I spent an entire day at TechShop, I went through at least 2 or 3 revisions of the design $(C))$. Further, this direct experience is educational as it uncovers unexpected learning needs and helps to identify what other competences are necessary (e.g. So when I did it with Shapeways initially, it didn't even cross my mind that it would be an issue for production. But when I did it at TechShop, and I had to wait, and wait and wait, I realised that it's not really a production primary path.[..] it's something you don't think about when you do it online because [..] you throw a design at a black box and they send it to you. (C)). This learning translates into higher organisational competences and the establishment of new routines (e.g. "I think that a really powerful thing for TechShop is understanding when to do it yourself, when to manufacture outside, and how to be able to make those decisions. (F)).

\subsubsection{Cultural environment}

With the exception of $\mathrm{D}$, interviewees universally referred to fab-spaces as environments supportive of individuals' undertakings, regardless of whether these were meant for personal commercial benefit. For A and $\mathrm{F}$ the most important aspect was the feeling of not being alone and isolated, which helped them to maintain the motivation, whilst for $\mathrm{G}$ the un-judgemental attitude was particularly important at the onset of a project, and in contrast with what he experienced with traditional business support organisations. "What's really difficult when you start a project is the feeling of being permanently evaluated. You have to give evidence that it's going to work, that it's a good idea, that there's a business plan. But at the beginning, there's no evidence of that because you don't know for sure. [..] Whereas in a FabLab, if you say you're 
trying to create a robot to travel to the moon, no one will laugh at you. They'll start asking questions about what you're going to do, they'll give you advice. And that's really nice. [..] You don't have to justify yourself, you're not asked if you're sure it's a valid project.” (G).

Although, opposite views were mentioned (see section 4.3.2), the collegial setup of fab-spaces, in particular those run by communities, was generally mentioned positively. B felt that the community recognizes that the success of an entrepreneur in her/his venture will reflect in benefits for the whole community. "And no one [cares] if they're giving you their best possible advice about something that you're going to turn into a business. [..] if you make money at this business, you're going to buy tools for the shop. Because you already like "doing hackerspace", lifting everyone else’s book. People are pretty egalitarian about stuff. [..] Just because of the karma from it, and how much it helped you." (B). The moral obligation to give back to the community was shared by those who attended community run fab-spaces (e.g. D, C), but also those who attended TechShops highlighted that getting involved in other activities beyond their ventures (e.g. contributing to other projects by becoming qualified as instructors $(\mathrm{H}))$ allowed them further benefits.

\subsection{What were the limitations of fab-spaces in the eyes of entrepreneurs?}

\subsubsection{Accessibility}

Several interviewees hinted at how important it was to be able to access the space, particularly in terms of physical distance (A, C, D, E, H). A abandoned his project for 2.5 years, because he could not afford other prototyping services, and only when he moved closer to a TechShop did he take up his idea again. The judgement of accessibility seems to occur against the costs to be sustained (monetary and time) (e.g. "I think TechShop existed but I think it was only [..] about an hour from here. [..] And there was just no way that I was going to be able to drive down in order to do this. [..] That's when TechShop opened [locally], which is an easy commute for me.” $(H))$. Web-based fab-spaces seem not to compensate for distance, especially at the start of the product design process, when fast iterations are required (see above). However, accessibility refers also to the rules and setup of fab-spaces in terms of the allowed time for using a machine (e.g. “Because you could only use the laser cutter for 2 hours. So in 2 hours, I had to figure out what worked and didn't work, only using it 3 times a week. That's why it took so long” (E)) or the opening hours (e.g.

"[TechShop] closes at midnight, which is fine for most people, but that's where I think that the hackerspaces Version 3 - FINAL - Accepted in the Special Issue "3D Printing: the Next Industrial Revolution" Int. J. of Manufacturing Technology and Management

Prof. Irene Petrick, Prof. Thierry Rayna, Dr. Ludmila Striukova, Eds 
here in town had an advantage. They were open 24/7." (C)), or time required (e.g. “hackerspace is selfgrown. So usually, there's a whole board of directors, and you have votes, and you have meetings. And I honestly wasn't interested in doing any of that. I only wanted to use the equipment.” (C)). C recognised how TechShop is perceived by most as too expensive in comparison to other community-run places. Even if he was more than pleased with the offer of services, he claimed that the monetary investment locks one in: “[..] you have this mindset that « oh, I've already spent in classes, I can't turn in my membership now, that would be a waste of money ». So, that's kind of the dark side there is. (C)". B, C and D remarked on the difference and expectations about fab-spaces standards (e.g. "The problem with it [Hackerspace], I guess, was there was quite a lack of rules and process that you kind of enjoy with TechShop.” (C); "[after frequenting a hackerspace] I went to the [university fab-space] and I was astonished by the large range of equipment there, the large space, the professional feel of the place, the quality of the organisation, knowing that everything was free there." (D)).

\subsubsection{Clashing cultural features/institutional setup}

Several felt that somehow exploiting fab-space facilities for their own venture somewhat ethically clashed with the spirit of the fab-spaces. In particular, D experienced a strong moral disapproval for his own status as an entrepreneur by the community of one fab-space: "It was interesting but they had an anti-capitalist mindset [... I. I told one of the guys that I had some commercial objectives and it was pretty shocking to him. I am not judgmental but this was not for me. (D)). Even when he changed fab-space, and found another where he felt better integrated, he personally decided that there was a limit to how much one can take (and exploit the space) and felt the pressure to be seen to give back. "I didn't want to be perceived as a free-rider, as someone who comes all smile, benefits from others' expertise than makes a profit out of it for himself. [..] It would not have been right to print them at the university fab-space because you would have used for a long period of time a machine which could have been needed for training purposes or by other users. (D)".

The issue of how to protect the product emerged for $\mathrm{D}$, as implicit in the rules of the fab-space there was the creative commons license. He felt that this was a limitation to continue develop his product there. 
C felt that the setup can be occasionally not flexible enough to respond to the users' needs. "I think that's where [..] a downside for TechShop is [..]. It's a large company. So, if you need something, if something needs to be changed and they aren't able to do it there, you'll have to deal with the management corporate and, you know, get your request filed and follow a process. ”(C).

\subsubsection{Tool/resources constraints}

Several mentioned limitations in the equipment available (low-quality machines, low number of machines, not the right type of equipment, more convenient to have something done elsewhere) as constraints for the use of fab-spaces (A, C, D, E, G, H). For instance, the development of printed circuit boards was mentioned by many as better outsourced than developed within the fab-space. Paradoxically, the availability of different types of equipment was mentioned negatively, as it induces the temptation to try to do everything on your own first, wasting precious time "I actually tried to make moulds, to inject-mould parts myself [...as] TechShop has a little injection moulding machine. [..]But they were not production quality parts that you could actually sell to anybody. So, that was probably 3 months [..] of wasted time there, in hindsight.”(H).

\section{Discussion}

With this work, we attempted to analyse the effects of the emergence and availability of fab-spaces on the entrepreneurial journey. For pragmatic reasons, we followed a simplified, and linear, venture creation process which encompasses three main stages: Ideation, Development and Production/commercialisation (as shown in section 2.1). Along this process, we evaluated the experiences of eight entrepreneurs and observed how the frequentation and exploitation of the fab-spaces influenced their ventures, in particular in terms of reducing the barriers along the way. Hence, the work described here provides an initial understanding of the mechanisms by which fab-spaces might impact on the entrepreneurial journey, and allows the formulation of several hypotheses and potential areas for future work.

\subsection{Entry effects of fab-spaces on deterring barriers}

The data collected suggest the hypothesis that there is no entry-effect (Autio, Kenney et al. 2014) of fabspaces on the intention to start an entrepreneurial journey (Degeorge and Fayolle 2011 ). On one hand, none of the entrepreneurs interviewed was stimulated towards creating a new business because of the fab-space 
environment. However, we are aware that this might be a by-product of our sampling approach. As fabspaces are relatively recent, at the time of our interviews, individuals might have been excluded from the study who recently had ideas for new businesses whilst frequenting the fab-spaces. We are also aware that "intention" is a 'hazy' concept, which often merges with the individual's aspiration for a career path rather than for a specific venture idea (Degeorge and Fayolle 2011 ).

Even if we did not observe any exogenous effect of fab-spaces on the 'entrepreneurial intention' (Degeorge and Fayolle 2011 ), the data confirm the hypothesis of a 'displacement' effect (Degeorge and Fayolle 2011). In fact, fab-spaces increase the opportunities to access resources and competences, lowering market barriers (D'Este, Iammarino et al. 2012), and in turn impact on the individual decision to move closer to setting up an independent business. For instance, the provision of moral and practical support was pivotal for G. He remarked on how the feeling of being supported, regardless of the demonstration of the likelihood of success, helped him to maintain his motivation, and to attempt to move forward by continuing to gather what was needed to be included in a business incubator. As a supportive culture is a decisive element in entrepreneurship, fab-spaces seem to be an important element of innovation systems which could complement other business support organisations with performance-based incentives (Stephan and Uhlaner 2010).

Linked to the above, we could observe that interacting with fab-spaces (in conjunction with other new institutional elements, such as crowdfunding platforms) seemed to influence the perception of failure and, as a result, the "threshold of performance" - i.e. the level of performance below which the constituents of the firm will decide to dissolve the organization (Gimeno, Folta et al. 1997). Fab-spaces allowed interviewees to initiate work towards their idea of venture, by pursuing small scale projects whose possible failure did not represent overwhelming costs to the individuals. They could maintain the perception of pursuing their overall idea of business, even in the face of setbacks. In fact, in many cases, the interviewees regarded their ventures as 'projects', rather than their overall business enterprises. This observation might contribute towards the emotive approach to explaining 'failure' (Khelil 2015), whereby fab-spaces change the perceived gap between actual rewards and the entrepreneur's anticipated expectations (Cooper and Artz 
1995). Also, this observation might contribute towards the understanding of how user-innovators might transition to become nascent-user-entrepreneurs (Shah and Tripsas 2007). It also supports Sarasvathy's hypothesis that, under the right circumstances, potentially every individual could become an entrepreneur (Sarasvathy 2004).

A further observation, is that the fab-spaces' influence (i.e. the provision of competences and resources, the support to individuals' motivation) is subjected to the conditions of offering. In particular, the accessibility of fab-spaces (in terms of cost, time and distance), and the institutional and cultural setup, emerged as moderating factors for the effect of the fab-spaces on entry barriers. The evidence collected showed the importance for entrepreneurs of being able to work personally with machines, and to be able to access local knowledge and expertise. This shows that, to encourage individuals to take the first steps towards fulfilling their venture, the "local buzz" dimension is more relevant than other types of knowledge channels (Bathelet, Malmberg et al. 2004). Furthermore, the fit of the entrepreneurs' culture with that of fab-spaces was also apparent as a moderator for the influence of the fab-space. Whilst the collegiality and the aspect of sharing resources was not a deterring issue for $\mathrm{B}$ and $\mathrm{C}$, the experience of $\mathrm{D}$ shows that some fab-spaces are permeated by a particularly strong anti-capitalistic culture, which can deter individuals from frequenting and acquiring the technical competences needed.

As a result of this analysis, several hypotheses emerge:

H1: The availability of fab-spaces does not affect the intention of individuals to become entrepreneurs

H2: The availability of fab-spaces positively affects the rate of individuals (with an entrepreneurial intention) who will start a venture

H3: The fab-spaces' impact on entrepreneurial entry is related inversely to their accessibility (in particular their geographic distance)

H4: Fab-spaces' impact on entrepreneurial entry is directly related to the cultural fit between fab-space and the entrepreneurs

\subsection{Post entry effects \& revealed barriers of fab-spaces}

Fab-spaces emerged as environments where individuals could learn the necessary skills to push their venture forward through direct experience (Levinthal 1996), imitation (Beckman and Haunschild 2002) and experimentation. Hence, they are in the position to help entrepreneurs to establish routines (Aldrich and 
Yang 2014). For instance, via fab-spaces, D acquired the technical knowledge necessary to interact with design consultants and hence developed an increased absorptive capacity (Cohen and Levinthal 1989). In addition, by continuously meeting new challenges and being presented with new knowledge, the interviewees appeared to be building the dynamic capabilities (Teece and Pisano 1994) needed to seek new knowledge and competences, and to be able to combine and recombine them to push their venture further.

The speed of learning, most importantly during the new product development and manufacturability stages, emerged as the most important advantage of fab-spaces. Those fab-spaces which allow a fast iteration of business approaches, and the discovery and anticipation of problems which might be found further down the line, seem to be more relevant for overcoming the revealed barriers. The availability at close range of individuals with technical (all interviewees), and entrepreneurial (A, B, F) experience, and the availability of different equipment types (A, B, C, F, H), seems to be important. Hence, entrepreneurs attending fab-spaces that had a thriving community, with varied expertise and varied technical machines, are more likely to proceed further in their ventures, and not fail or to drop out at a later stage, than those who rely on on-line and remote assistance.

The quality of equipment, and its speed, becomes more relevant towards the end of the manufacturability stage, to allow entrepreneurs to access and test a market, with the production and diffusion of a small batch of their products.

Also for revealed barriers, there seem to be moderating factors on the impact of fab-spaces, linked to cultural and institutional setups (e.g. the costs in terms of personal involvement with the fab-space).

H5: Physical fab-spaces will positively impact the rate of late failure (or no failure) in ventures

H6: The quality of machines provided by fab-spaces positively impacts the rate of late failure (or no failure) in ventures

H7: Fab-spaces' impact is directly proportional to the cultural fit between fab-space and the entrepreneurs 


\section{Conclusions}

Notwithstanding the intrinsic limitations of the paper, chiefly the small and imperfect sample, and the data reconstructed from accounts referred to past experience, this paper has shown initial evidence of how fabspaces can lower barriers in the new product development/entrepreneurial process. Two main conclusions can be drawn:

1. The observations made in this paper support the idea that fab-spaces could encourage the individuals, who already manifested an intention to become entrepreneurs, as they can impact on their "effectual path" (Sarasvathy 2001). Through fab-spaces, entrepreneurs can find better conditions to operate, with affordable losses and limited risk-taking when uncertainty is very high. Hence, fab-spaces might help to reduce the fear of failure (Khelil 2015) and to modify the "performance threshold", i.e. "The level of performance below which the dominant organizational constituents will act to dissolve the organization" (Gimeno, Folta et al. 1997).

2. Fab-spaces are a new setting in which entrepreneurs will be enabled to learn the skills and establish a correct set of routines to grow and survive (Aldrich and Yang 2014). They enable a particular feature of a high "learning speed".

a. At the beginning of the venture process, the quick iterations of designs help nascent entrepreneurs to understand the key features of the products and how to manufacture them.

b. At a later stage the availability of professional-level production technologies and accessible supply chains for material procurement help nascent entrepreneurs to test the market and decide whether to scale-up their operations.

Both these advantages are however moderated by the characteristics of the fab-spaces' setup - in particular the accessibility (i.e. distance and cost) - at the earliest stages of the venture, and the cultural alignment between the fab-space community with that of the entrepreneurs.

The above indicates that fab spaces may now be positioned amongst other Knowledge Intensive Business Services (Consoli and Elche-Hortelano 2010), as a new and complementary category in the group of "business support services as incubators and science parks" (Phan, Siegel et al. 2005). 
Future work should attempt to deepen these observations, and to gather more extensive data to refine and test these hypotheses. Further, as fab-spaces support entrepreneurs mostly by virtue of the communities attending these spaces, more research is needed to understand how these 'meta-organisations' can be designed (Gulati, Puranam et al. 2012) to support organisational sustainability in the long term, and also potential organisational scale-up. One step towards the achievement of this understanding might be to develop, following Landry et al. (2013), an "ecology" of fab-spaces according to their business models.

\section{Acknowledgements}

This project has been carried out within the UK - EPSRC - ESRC-sponsored project "Bit-by-bit: Capturing value from the digital fabrication revolution" (EP/K039598/1). A warm “thank you!" goes to those who helped developing this paper. In particular, their colleagues Dr Tim Minshall and Dr Simon Ford for their support during the work, Prof. Howard Aldrich, Prof. Gianni Lorenzoni and the anonymous reviewers for the extremely helpful support and welcome suggestions.

Data in this paper has been anonymised to protect authors' confidentiality. Additional raw data related to this publication cannot be openly released; the raw data contains transcripts of interviews, but the interviewees di not consent to open data sharing. 


\section{Appendices}

\subsection{Interview questionnaire}

\begin{tabular}{|c|c|c|}
\hline Stage & Theme & Questions \\
\hline \multirow{4}{*}{ 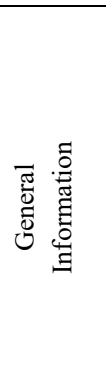 } & General information about the interviewee & $\begin{array}{l}\text { - What is your background? } \\
\text { - How many people are involved in your venture? Where did you meet? }\end{array}$ \\
\hline & Stage of entrepreneurship & - At what stage of your product development are you? \\
\hline & Fab-spaces & - What fab-spaces did you use? \\
\hline & General information on the company & $\begin{array}{l}\text { - How old is your business? } \\
\text { - What was its last annual turnover? } \\
\text { - How many employees? }\end{array}$ \\
\hline 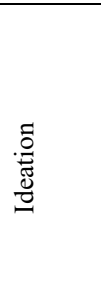 & Opportunity identification & $\begin{array}{l}\text { - When did you first get your idea? } \\
\text { - When you first joined a fab-space, was it with the idea of developing a product } \\
\text { and becoming an entrepreneur? } \\
\text { - If yes, did you already have an idea of a product to develop? } \\
\text { - Did the other users/staff of the fab- space help you develop this idea? } \\
\text { - Did you use other services to develop your idea? } \\
\text { - If so, which ones and Why? }\end{array}$ \\
\hline 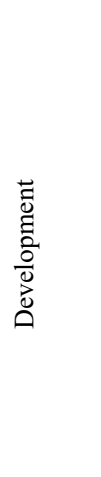 & Product development & $\begin{array}{l}\text { - When did you make your first prototype? (from simple sketch) } \\
\text { - What machines did you use to build your prototype? } \\
\text { - How many prototypes did you make? } \\
\text { - Did you need to take lessons (e.g. to use CAD software and the machines? Did } \\
\text { you take many lessons or are you a self-taught person?) } \\
\text { - How much money did you spend during the prototyping stage? (including classes, } \\
\text { materials, membership, ...) } \\
\text { - What skills did you lack? How did the Fab-space help you to overcome this lack } \\
\text { of knowledge? } \\
\text { - Did you use other services than the one provided by the hackerspace to develop } \\
\text { your product? } \\
\text { - If so, why? }\end{array}$ \\
\hline 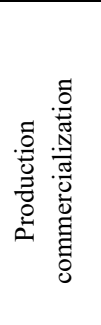 & $\begin{array}{l}\text { Production, commercialization and business } \\
\text { financing }\end{array}$ & $\begin{array}{l}\text { - If there has already been a first production, how was it made? } \\
\text { - Did the fab-space help you to start your production? If so, how? } \\
\text { - Did the fab-space help you to reach your first customers? If so, how? } \\
\text { - Did you get external funds? If so, from whom? Any help from the fab- space? } \\
\text { - How did you start the production/reached your first customers? }\end{array}$ \\
\hline
\end{tabular}

Version 3.0 - Submitted to the Special Issue "3D Printing: the Next Industrial Revolution" - Int. J. of Manufacturing Technology and Management

Prof. Irene Petrick, Prof. Thierry Rayna, Dr. Ludmila Striukova, Eds 


\section{Figures}

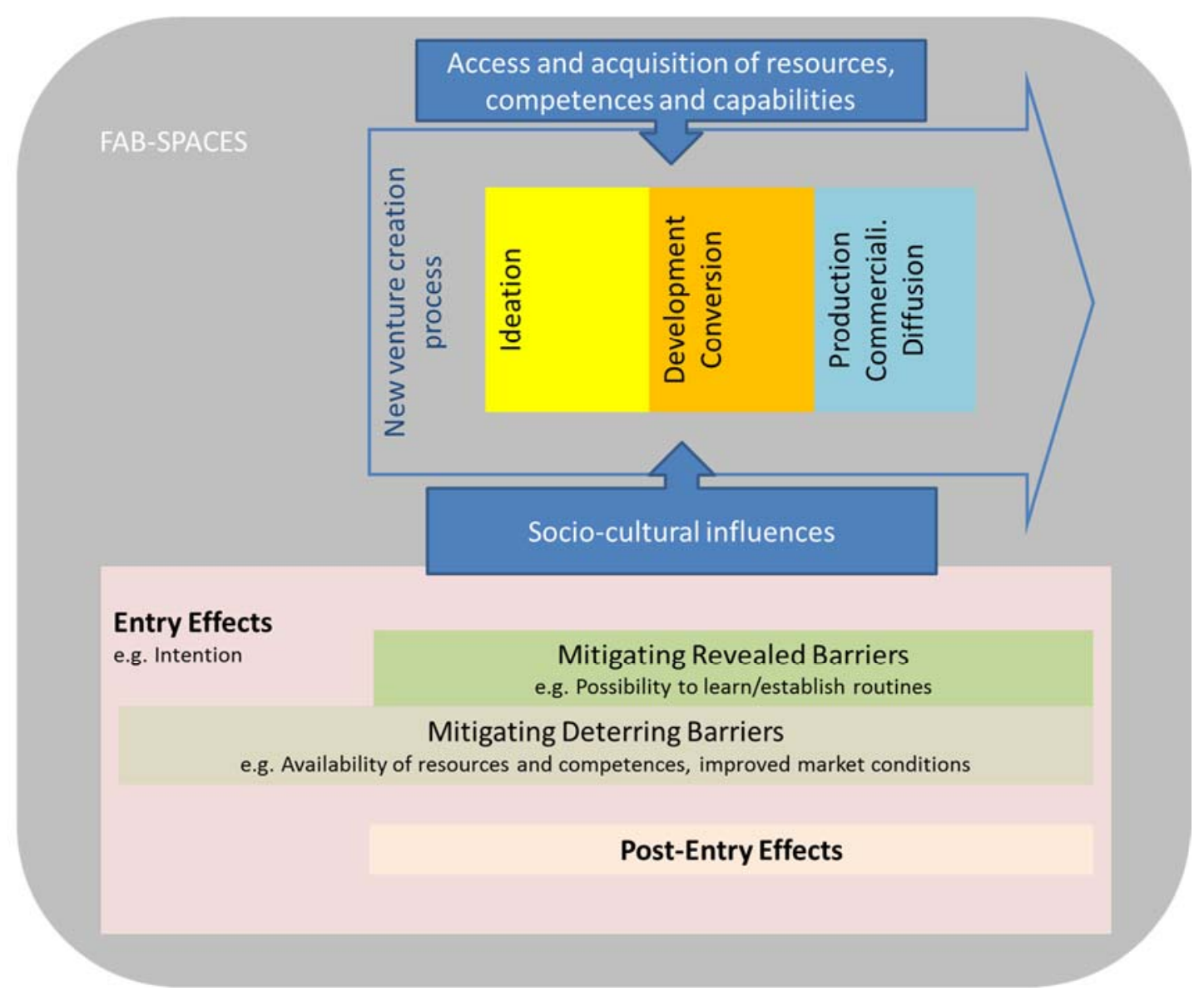

Fig. 1 The exploratory framework to understand Fab-spaces influences on the entrepreneurs' venture creation process

Version 3.0 - Submitted to the Special Issue "3D Printing: the Next Industrial Revolution” - Int. J. of Manufacturing Technology and Management

Prof. Irene Petrick, Prof. Thierry Rayna, Dr. Ludmila Striukova, Eds 


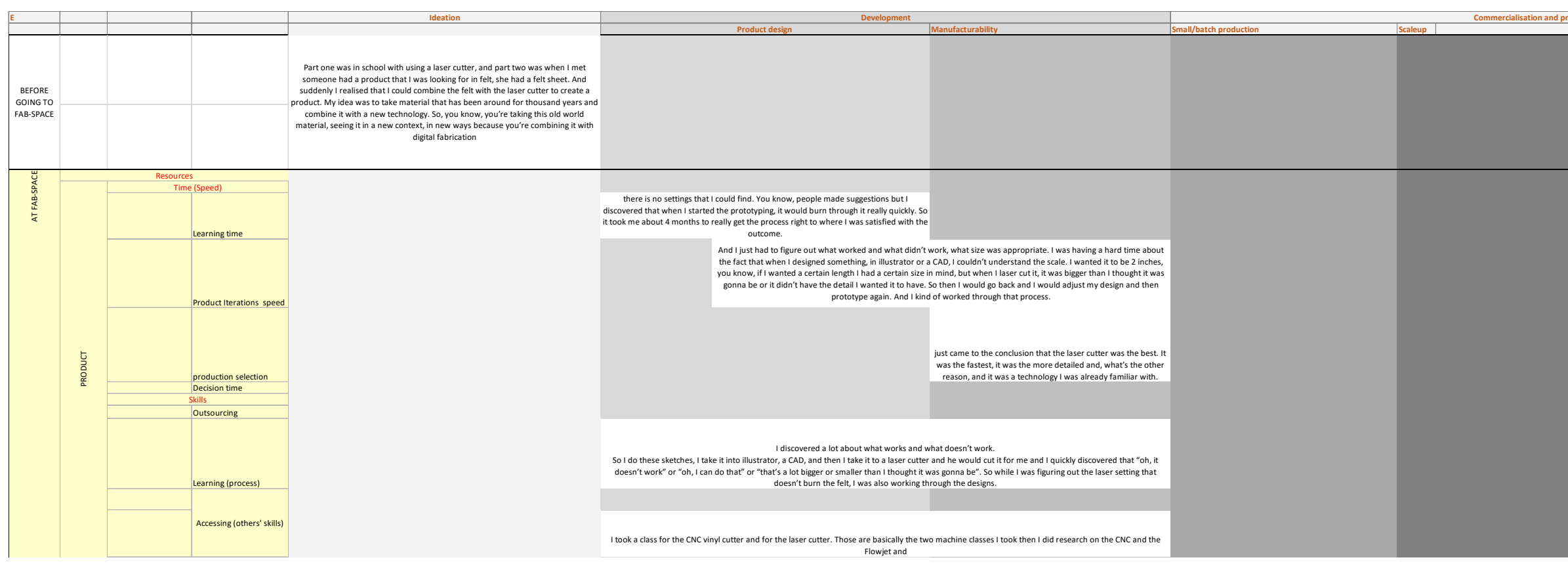

Fig. 2 A small portion of the data analysis sheet 


\section{References}

Aldrich, H. (2014). The democratization of entrepreneurship? Hackers, makerspaces, and crowdfunding. Department of sociology, University North Carolina at Chapel Hill.

Aldrich, H. E. and T. Yang (2014). "How do entrepreneurs know what to do? learning and organizing in new ventures." Journal of Evolutionary Economics 24(1): 59-82.

Alvarez, S. A., J. B. Barney and P. Anderson (2013). "Forming and Exploiting Opportunities : The Implications of Discovery and Creation Processes for Entrepreneurial and Organizational Research. ." Organisation Science 24(1): 301 - 317.

Anderson, C. (2012). Makers. The new industrial revolution. London, The Random House Group Limited.

Ardichvili, A., R. Cardozo and S. Ray (2003). "A theory of entrepreneurial opportunity identification and development." Journal of Business Venturing 18(1): 105-123. .

Autio, E., M. Kenney, P. Mustar, D. Siegel and M. Wright (2014). "Entrepreneurial innovation: The importance of context." Research Policy 43(7): 1097-1108.

Barney, J. B. (2001). "Is the resource-based "view" a useful perspective for strategic management research? Yes." Academy Of Management Review 26(1): 41-56.

Bathelet, H., A. Malmberg and P. Maskell (2004). "Clusters and Knowledge: local buzz, global pipelines and the process of knowledge creation." Progress in Human Geography 28(1): 31-56.

Beckman, C. M. and P. R. Haunschild (2002). "Network learning: the effects of partners' heterogeneity of experience on corporate acquisitions." Admin Sci Q 47(1): 92-124.

Bhave, M. P. (1994). "A process model of entrepreneurial venture creation." Journal of Business Venturing 9(3): 223-242.

Birtchnell, T. and J. Urry (2013). "Fabricating Futures and the Movement of Objects." Mobilities 8(3): 388-405.

Bogers, M. and W. Horst (2014). "Collaborative prototyping: Cross-fertilization of knowledge in prototype-driven problem solving." Journal of Product Innovation Management 31(4): 744-764.

Brem, A. (2007). The Boundaries of Innovation and Entrepreneurship, Springer.

Brem, A. (2011). "Linking innovation and entrepreneurship - literature overview and introduction of a process-oriented framework." International Journal of Entrepreneurship and Innovation Management 14(1): 6-35.

Cohen, W. M. and D. A. Levinthal (1989 ). "Innovation and Learning: The Two Faces of R\&D." Economic Journal 99: 569-596.

Consoli, D. and D. Elche-Hortelano (2010). "Variety in the knowledge base of Knowledge Intensive Business Services." Research Policy 39(10): 1303-1310.

Cooper, A. C. and W. A. Artz (1995). "Determinants of satisfaction for entrepreneurs." J. Bus. Ventur 10 (6): 439-457. 
Creswell, J. W. (2003). Research design: qualitative, quantitative, and mixed method approaches. . London and Thousand Oaks, CA., Sage Publications.

D'Este, P., S. Iammarino, M. Savona and N. von Tunzelmannc (2012). "What hampers innovation? Revealed barriers versus deterring barriers." Research Policy 41: \$82-488.

Degeorge, J.-M. and A. Fayolle (2011 ). "The entrepreneurial process trigger: a modelling attempt in the French context." Journal of Small Business and Enterprise Development 18(2): 251-277.

Dougherty, D., P. Thomas, S. Chang, S. Hoefer, I. Alexander and D. Mcguire (2013). Makerspace Playbook, School edition.

Elliot, J. (2005). Using Narrative in Social Research: Qualitative and Quantitative Approaches. Thousand Oaks, CA, Sage.

Fayolle, A. (2007). Entrepreneurship and New Value Creation: The Dynamic of the Entrepreneurial Process. New York, NY, Cambridge University Press.

Gavetti, G., H. R. Greve, D. A. Levinthal and W. Ocasio (2012). "The Behavioral Theory of the Firm: Assessment and Prospects." Academy of Management Annals 6(1): 1-40.

Gershenfeld, N. (2007). Fab: The Coming Revolution on Your Desktop--from Personal Computers to Personal Fabrication, Basic Books, Inc.

Gimeno, J., T. B. Folta, A. C. Cooper and C. Y. Woo (1997). "Survival of the Fittest? Entrepreneurial Human Capital and the Persistence of Underperforming Firms." Administrative Science Quarterly 42(4): 750-783.

Glaser, B. G. and A. L. Strauss (1967). The Discovery of Grounded Theory: Strategies for Qualitative Research. Chicago Aldine.

Gulati, R., P. Puranam and M. Tushman (2012). "Meta-organization design: Rethinking design in interorganizational and community contexts." Strategic Management Journal 33(6): 571-586.

Hansen, M. T. and J. Birkinshaw (2007). "The innovation value chain." Harvard Business Review 85(6): 121-130+142.

Hitt, M., D. Ireland, M. Camp and D. Sexton (2001). "Strategic entrepreneurship: entrepreneurial strategies for wealth creation. ." Strategic Management Journal 491: 479-491.

Jennings, P. D., R. Greenwood, M. D. Lounsbury and R. Suddaby (2013). "Institutions, entrepreneurs, and communities: A special issue on entrepreneurship." Journal of Business Venturing 28(1): 1-9.

Katila, R. and S. Shane (2005). "When does lack of resources make new firms innovative?" Academy of Management Journal 48(5): 814-829.

Khelil, N. (2015). "The many faces of entrepreneurial failure: Insights from an empirical taxonomy." Journal of Business Venturing.

Landry, R., N. Amara, J. S. Cloutier and N. Halilem (2013). "Technology transfer organizations: Services and business models." Technovation 33(12): 431-449.

Levinthal, D. (1996). Learning and schumpeterian dynamics. . Organization and strategy in the evolution of enterprise. Malerba F and D. G. London, Macmillan: 27-41.

Version 3.0 - Submitted to the Special Issue "3D Printing: the Next Industrial Revolution” - Int. J. of Manufacturing Technology and Management

Prof. Irene Petrick, Prof. Thierry Rayna, Dr. Ludmila Striukova, Eds 
Lieblich, A., R. Tuval-Mashiach and T. Zilber (1998). Narrative Research: Reading, Analysis and Interpretation. Thousand Oaks, CA, Sage.

Martinez, M. A. and H. E. Aldrich (2011). "Networking strategies for entrepreneurs: Balancing cohesion and diversity." International Journal of Entrepreneurial Behaviour and Research 17(1): 7-38.

Mascitelli, R. (2000). "From experience: harnessing tacit knowledge to achieve breakthrough innovation." Journal of Product Innovation Management 17(3): 179-193.

Miotti, L. and F. Sachwald (2003). "Co-operative R\&D: Why and with whom? An integrated framework of analysis." Research Policy 32(8): 1481-1499.

Moilanen, J. (2012). Emerging Hackerspaces - Peer-Production Generation. Open Source Systems: Long-Term Sustainability. I. H. e. al., IFIP AICT - International Federation for Information Processing: 94-111.

Moilanen, J. and T. Vadén (2013). "3D printing community and emerging practices of peer production." First Monday 18(8).

Nanda, R. and J. Sorensen (2010). "Workplace peers and entrepreneurship." Management Science 56 (7): 1116-1126.

Patton, M. Q. (1990). Qualitative Evaluation and Research Methods Newbury Park, CA:, Sage Publications.

Petrick, I. J. and T. W. Simpson (2013). "3D printing disrupts manufacturing." Research Technology Management 56(6): 12-16.

Phan, P. H., D. S. Siegel and M. Wright (2005). "Science parks and incubators: Observations, synthesis and future research." Journal of Business Venturing 20(2): 165-182.

Ries, E. (2011). The lean startup New York, Crown Business - Random House, Inc.

Rigi, J. (2013). "Peer production and Marxian communism: Contours of a new emerging mode of production." Capital and Class 37(3): 397-416.

Roper, S., J. Du and J. H. Love (2008). "Modelling the innovation value chain." Research Policy 37(6-7): 961-977.

Sarasvathy, S. D. (2001). "Causation and effectuation: Toward a theoretical shift from economic inevitability to entrepreneurial contingency." Academy of Management Review 26(2): 243-263.

Sarasvathy, S. D. (2004). "The questions we ask and the questions we care about: reformulating some problems in entrepreneurship research." Journal of Business Venturing 19(5): 707-717.

Shah, S. and M. Tripsas (2012). "When do user innovators start firms? A theory of user entrepreneurship." REVOLUTIONIZING INNOVATION: USERS, COMMUNITIES, AND OPEN INNOVATION, MIT Press, Forthcoming: 12-078.

Shah, S. K. and C. C. Mody (2014). Creating a context for entrepreneurship: Examining how users' technological and organizational innovations set the stage for entrepreneurial activity. Chapter 9 in Governing Knowledge Commons, Oxford University Press: 313. 
Shah, S. K. and M. Tripsas (2007). "The accidental entrepreneur: The emergent and collective process of user entrepreneurship." Strategic Entrepreneurship Journal 1(1-2): 123140 .

Shane, S. (2000). "Prior Knowledge and the Discovery of Entrepreneurial Opportunities." Organization Science 11(4): 448-469

Shane, S. A. and S. Venkataraman (2000). "The promise of entrepreneurship as a afield of research." Academy of management review 25(1): 217-226.

Stephan, U. and L. Uhlaner (2010). "Performance-based vs socially supportive culture:a cross-national study of descriptive norms and entrepreneurship." Journal ofInternational Business Studies 41 (8): 1347-1364.

Strauss, A. and J. Corbin (1994). Grounded theory methodology: an overview. Handbook of qualitative research. N. K. Denzin and Y. S. Lincoln. Tthousand Oaks, Sage: 273-285.

Teece, D. and G. Pisano (1994). "The Dynamic Capabilities of Firms: an Introduction." Industrial and Corporate Change 3(3): 537-556.

Thornton, P. H., R.-S. D. and D. Urbano (2011). "Sociocultural Factors and Entrepreneurial Activity: an Overview." International Small Business Journal 29(2): 105-118.

Tidd, J. (2014). "Conjoint innovation: Building a bridge between innovation and entrepreneurship." International Journal of Innovation Management 18(1).

Troxler, P. and S. Schweikert (2010). Developing a Business Model for Concurrent Enterprising at the Fab Lab. Proceedings of the 16th International Conference on Concurrent Enterprising. Lugano, Switzerland.

Utterback, J. M. (1971). "Process of innovation. A study of the origination and development of ideas for new scientific instruments." IEEE TRANSACTIONS ON ENGINEERING MANAGEMENT EM-18(4): 124-131.

Von Hippel, E. (2005). Democratizing Innovation. Boston, The MIT Press.

Woo, C. Y., A. C. Cooper and W. C. Dunkelberg (1991). "The development and interpretation of entrepreneurial typologies." Journal of Business Venturing 6(2): 93-114.

Yin, R. K. (2003). Case study research: Design and methods. Thousand Oaks, CA, Sage.

Yin, R. K. (2009). Case Study Research: Design and Methods (Applied Social Research Methods) Thousand Oaks, CA, Sage Publications, Inc.

Zahra, S. A., M. Wright and S. G. Abdelgawad (2014). "Contextualization and the advancement of entrepreneurship research." International Small Business Journal 32(5): 479500 . 